\title{
Fiscal Planning and Implementation: Euro Area Analysis Based on Real Time Data
}

\author{
Maritta Paloviita ${ }^{1, *}$ \\ ${ }^{1}$ Bank of Finland, Monetary Policy and Research, P.O. Box 160, 00101 Helsinki, Finland \\ *Correspondence: Tel: 358-50-341-4421 E-mail: maritta.paloviita@bof.fi
}

Received: November 6, 2013 Accepted: December 17, 2013 Published: January 20, 2014

doi:10.5296/rae.v6i1.4515 URL: http://dx.doi.org/10.5296/rae.v6i1.4515

\begin{abstract}
The aim of this study is to explore discretionary fiscal policies in the euro area during the time of monetary union (EMU). Ex ante budget plans and policy changes during budget implementation are investigated using real time data from the OECD Economic Outlook publications. The particular focus of the study is on fiscal adjustment to the recent financial crisis and the subsequent global recession. Estimated fiscal policy reaction functions indicate that in the EMU period ex ante fiscal plans have basically been long-term oriented and counter-cyclical in the euro area. In the course of the budgetary year, policies have typically been adjusted due to data revisions and new business cycle information. The crisis had a clear impact on discretionary policies. The periphery countries clearly adjusted their policies already in the budgetary planning stage, but other countries mainly reacted to the crisis during budget implementation. We provide evidence that short-term counter-cyclical fiscal policies may not have been consistent with sound and sustainable public finances.
\end{abstract}

Keywords: fiscal policy, real time data, planning stage, implementation stage, cyclical sensitivity, economic crisis

JEL Codes: E62, E32 


\section{Introduction}

During the financial crisis and subsequent global recession, public finances weakened substantially in the euro area. The crisis clearly contributed to the increasing heterogeneity of government bond yields, as market participants started to pay more attention to fiscal fundamentals and country-specific risks when pricing sovereign bonds (Note 1). The largest increases in government bond yields have been observed in Greece, Ireland, Italy, Portugal and Spain. These euro area periphery countries have been under intense market pressure for years.

The crisis is not the only reason for the current debt problems in the euro area. In many countries weak competitiveness, rising financial costs and serious banking sector problems in the pre-crisis years have also contributed to slow growth and debt accumulation. Debt ratios differed quite a lot across countries already prior to the monetary union. In 1998 the average euro area debt ratio was about $65 \%$, but it amounted to $85 \%$ in 2010 . In spite of very divergent economic developments in the euro area, it is the orientation of fiscal policy that ultimately explains the observed heterogeneity of debt accumulation.

The EU fiscal framework has been renewed recently, in response to the current sovereign debt crisis. Reforms have been made in order to deal with the crisis and to ensure long run fiscal sustainability in the member states. New and updated regulations as well as new, more efficient ways for imposing sanctions have been decided on. The new framework includes common rules, according to which individual countries must conduct economic policy.

Economic monitoring and forecasting are central in the new EU fiscal framework. They are always based on uncertain real time information. When making decisions, policymakers find it difficult to assess the current or expected state of the economy with sufficiently high certainty and, hence, cannot to an acceptable degree of confidence predict when and how policy decisions affect the economy. The effects of automatic stabilizers on budget balances are also difficult to estimate. Real time uncertainty can contribute to surprisingly weak public finances and unexpected debt accumulation, as was observed during the crisis.

Fiscal policy reaction functions illustrate how fiscal policies react to the state of the economic cycle. The main idea is to investigate whether policy decisions have dampened economic cycles (counter-cyclical policy) or whether they have increased macroeconomic fluctuations (pro-cyclical policy). Real time uncertainty exposes policymakers to an important risk of inappropriate policy decisions. When fiscal policy analysis is based on real time data, we are able to analyze ex ante fiscal plans and new policy decisions made during budget implementation stage separately. Ex ante fiscal plans determine the intended path of fiscal policy. Policy changes during the budget implementation stage refer to fiscal decisions made in the course of the budgetary year in response to data revisions and new economic information.

Our study contributes to the current literature on fiscal policy rules and policy debate about the new EU fiscal framework by examining euro area discretionary fiscal policies since the late 1990s. Our contribution is especially related to the recent crisis, since, contrary to many 
other studies, the data set of this study covers also the crisis years. Moreover, increasing heterogeneity in the euro area is taken into account in our analysis, since we analyse euro area fiscal policies in the periphery countries and other countries separately. The planning and implementation stages are distinguished via real time panel data constructed from the OECD Economic Outlook publications (June and December issues). Although the final data for recent years have not been published yet, the currently available real time information enables us to investigate possible policy changes during the crisis. Both fiscal policy reaction functions and equations explaining policy changes during budget implementation are estimated using panel data for the euro area. Also policies in two country groups, i.e. in the periphery countries and other euro area countries are investigated separately. The fiscal adjustment to the recent crisis is analyzed in more detail.

The results suggest that in the EMU period euro area planned fiscal policies have basically been long-term oriented and counter-cyclical. In the implementation stages new policy decisions have been made in response to unexpected economic developments. We provide evidence that the crisis had a definite impact on discretionary policies. The periphery countries clearly adjusted their policies already in the budgetary planning stage, but other countries mainly reacted to the crisis during budget implementation. Our analysis suggests that tight monitoring of macroeconomic imbalances and accurate forecasting are central in good fiscal governance. We also find evidence that short-term counter-cyclical fiscal policies are a necessary but not a sufficient condition for sound public finances. In order to maintain fiscal discipline and avoid excessive indebtedness, binding longer term fiscal orientation and continuous monitoring of budgeting processes are needed.

The paper proceeds as follows. Section 2 presents the data and analyses the forecast accuracy. Empirical analysis is reported in section 3 and conclusions are drawn in section 4.

\section{Data Description}

Annual real time data for the period 1997-2010 are constructed using OECD Economic Outlook publications, for June and December, issues No. 61-88. Twelve euro area countries are included in the study. They have been divided into two country groups on the basis of recent developments in the government bond yields. Greece, Ireland, Italy, Portugal and Spain belong to the group of periphery countries (Group A). Correspondingly, Austria, Belgium, Finland, France, Luxembourg, Germany and Netherlands belong to the group of other euro area countries (Group B). Each of the Outlook issues includes a time series for the following variables: real GDP growth rate, ratio of cyclically adjusted primary balance to potential GDP (Note 2), ratio of gross government debt to GDP (Maastricht debt), and the OECD's production function -based estimate of the output gap, for each country (Note 3). The panel data include more than a decade of real time lagged values of all the variables, annual real time estimates of current-year values, and real time forecasts for the following calendar year. The revised (final) data, for our purposes, are from the latest annual Economic Outlook (December 2010, No. 88, Note 4). 
There are several advantages to using OECD data in the real time fiscal policy analysis. For example, all the series are comparable across countries, since they are constructed using the same methodology. Moreover, OECD forecasts contain policy makers' perceptions of fiscal policy measures and economic developments, since national authorities contribute regularly to the OECD forecasting process. The December issues provide information available at times when fiscal plans are made. Correspondingly, the June issues reflect the real time information available to policy makers during budget implementation stages.

As an example, Figures 1-4 in Appendix 1 show real time and revised estimates of all the variables in the data set for France, Germany, Italy and Spain. These countries dominate the euro area, with a combined weight of about $80 \%$. In Figures 1-4 the REV refers to final information and FOR to forecast made in the previous December (at the time of fiscal planning). Correspondingly, variables CU_J and CU_D are real time June and December estimates for the current year (assessed in the middle and at the end of the budgetary year).

Typically, real time estimates of cyclically adjusted primary balances have been too optimistic, as shown in Figure 1. Balances have been positive in Italy since the late 1990's and in Spain until the year 2007. In France and Germany balances have been quite close to zero. In the pre-crisis years, the debt ratios were about $60 \%$ in France and Germany and over $100 \%$ in Italy (see Figure 2). Instead, in Spain, it decreased from about 60 to about $35 \%$. The crisis increased the debt ratios especially in the periphery countries.

Assessing economic growth and output gap developments in real time has proven to be extremely challenging, as shown in Figures 3 and 4 in Appendix 1. Especially output gap estimates have been rather inaccurate. Typically, there seems to be a negative bias in real time output gap estimates. Sharp decreases in real growth and the output gaps in 2009 were not anticipated in the previous year. Only in Germany growth was surprisingly high in 2010.

Table 1 summarizes information on the average accuracy of December forecasts. We compare real time estimates of current-year outcomes with previous-year forecasts of those outcomes. Three different periods are compared: 1998-2010 (the whole sample), 1998-2007 (pre-crisis period) and 2008-2010 (crisis period). As shown in Table 1, forecasts were not very accurate during the recession years; both the Mean Absolute Errors (MAE) and Root Mean Squared Errors (RMSE) were twice as large as in the previous years and increases in debt were systematically underestimated. Upon comparing the two country groups in Table 1 we can conclude that in terms of pre-crisis forecast accuracy the differences are small.

Figures in Appendix 2 show how real time estimates for the year 2009 have evolved over time. Until the end of 2008, the primary balances were projected to be non-negative or very close to zero in 2009. In June 2009 the estimates were substantially revised downwards in Spain, where, in particular, authorities have continued to revise the balance downwards significantly over time. 
Table 1. Forecast Accuracy in the Euro Area

\begin{tabular}{|c|c|c|c|c|c|c|c|c|c|}
\hline 1998-2010 & ME & $\begin{array}{l}\text { MAE } \\
\text { EA12 }\end{array}$ & RMSE & ME & $\begin{array}{c}\text { MAE } \\
\text { Group A }\end{array}$ & RMSE & ME & $\begin{array}{c}\text { MAE } \\
\text { Group B }\end{array}$ & RMSE \\
\hline $\begin{array}{l}\text { Cyclically adj. primary } \\
\text { balance, } \% \text { of potential GDP }\end{array}$ & -0.388 & 1.111 & 1.609 & -0.896 & 1.519 & 2.336 & -0.024 & 0.819 & 1.090 \\
\hline $\begin{array}{l}\text { Ratio of gross government } \\
\text { debt to GDP }\end{array}$ & 0.787 & 3.235 & 4.392 & 1.497 & 4.163 & 5.804 & 0.279 & 2.573 & 3.384 \\
\hline $\begin{array}{l}\text { Ouput gap, } \% \text { of potential } \\
\text { GDP }\end{array}$ & -0.053 & 0.808 & 1.116 & 0.043 & 0.782 & 1.060 & -0.121 & 0.827 & 1.156 \\
\hline Real GDP growth, \% & -0.442 & 1.178 & 1.572 & -0.501 & 1.071 & 1.477 & -0.400 & 1.256 & 1.640 \\
\hline 1998-2007 & & EA12 & & & Group A & & & Group B & \\
\hline $\begin{array}{l}\text { Cyclically adj. primary } \\
\text { balance, } \% \text { of potential GDP }\end{array}$ & 0.060 & 0.813 & 1.003 & -0.224 & 0.969 & 1.242 & 0.264 & 0.702 & 0.832 \\
\hline $\begin{array}{l}\text { Ratio of gross government } \\
\text { debt to GDP }\end{array}$ & -0.340 & 2.480 & 3.041 & -0.317 & 3.080 & 3.878 & -0.357 & 2.051 & 2.442 \\
\hline $\begin{array}{l}\text { Ouput gap, } \% \text { of potential } \\
\text { GDP }\end{array}$ & 0.080 & 0.668 & 0.825 & 0.202 & 0.682 & 0.901 & -0.008 & 0.658 & 0.771 \\
\hline Real GDP growth, \% & -0.138 & 0.903 & 1.097 & -0.099 & 0.731 & 0.897 & -0.166 & 1.026 & 1.241 \\
\hline 2008-2010 & & EA12 & & & Group A & & & Group B & \\
\hline $\begin{array}{l}\text { Cyclically adj. primary } \\
\text { balance, } \% \text { of potential GDP }\end{array}$ & -1.709 & 2.051 & 2.627 & -3.065 & 3.278 & 4.119 & -0.740 & 1.174 & 1.562 \\
\hline $\begin{array}{l}\text { Ratio of gross government } \\
\text { debt to GDP }\end{array}$ & 4.574 & 5.745 & 6.977 & 7.546 & 7.771 & 9.541 & 2.452 & 4.298 & 5.145 \\
\hline $\begin{array}{l}\text { Ouput gap, } \% \text { of potential } \\
\text { GDP }\end{array}$ & -0.539 & 1.308 & 1.646 & -0.487 & 1.116 & 1.338 & -0.576 & 1.446 & 1.865 \\
\hline Real GDP growth, $\%$ & -1.456 & 2.096 & 2.529 & 1.840 & 2.203 & 2.552 & 1.182 & 2.020 & 2.513 \\
\hline
\end{tabular}

$$
\mathrm{ME}=\text { mean error, } \mathrm{MAE}=\text { mean average error, } \mathrm{RMSE}=\text { root mean squared error }
$$

All in all, the evidence suggests that the crisis, which swept through all euro area countries at the same time, had an unexpectedly large effects on the euro area economies. One might well speculate that the exceptionally large implied forecast errors have had an impact on fiscal policies in the crisis years. Due to increased uncertainty, growth prospects and primary balance developments were very difficult to assess in real time, partly due to huge data revisions.

Real time data revisions have also been analyzed in de Castro et al. (2013). Using a pool of real time data for fifteen EU countries over the period 1995-2008, they show that preliminary releases of government balances are systematically biased and poor predictors of subsequent releases. According to their findings, political cycles affect data revisions. Beetsma et al. (2011) have investigated the determinants of deviations of ex-post budget outcomes from first-release outcomes published towards the end of the year of budget implementation. They argue that tight fiscal rules, medium-term budgetary frameworks and budgetary transparency can make first-release figures more informative about the eventual outcomes. Frankel and 
Schreger (2012) argue that official budget agencies make systematic forecast errors, which can defeat fiscal discipline. They show that governments' budget forecasts are biased in the optimistic direction, especially in the euro area. Hughes Hallett et al (2012) examine how reliable cyclically adjusted budget balances are in real time. They analyze twelve OECD countries for 1995-2008 and find that real time cyclically adjusted budget balances have low power in detecting fiscal slippages and in correctly identifying fiscal improvements. They argue that cyclically adjusted budget balances are systematically less reliable under conditions of poor or deteriorating public finances.

\section{Empirical Analyses}

Next, we enter into a statistical analysis of euro area discretionary fiscal policies using simple regressions and the panel real time data as described above. Ex ante fiscal plans (planned budgets) and policy changes in the course of the budgetary year (updated fiscal plans) are examined separately. In addition to average fiscal policies, two separate country groups are examined in order to explore possible differences in policies between the periphery countries and other countries. The impact of the recent crisis on policy decisions is examined in more detail.

\subsection{Ex ante fiscal plans}

Depending on the exact specification, the fiscal policy reaction function indicates the response of the fiscal authority to the current or forecasted state of the economy. Once parameterized, the cyclical properties of such reaction functions as well as the persistence of the implied planned policies depend on the (estimated or calibrated) values of the parameters themselves. Fiscal policy reaction functions have typically been investigated using revised data (see for example Lane 2003a, Lane 2003b, European Commission 2004 and Staehr 2008). In recent studies also real time information has been used (see for example Cimadomo 2012, Beetsma and Giuliodori 2010, Beetsma et al. 2009 and Beetsma et al. 2010, Note 5).

Discretionary fiscal policy plans for the following year are generally made after the summer. By the end of the year, fiscal authorities approve the budget for the following year. Since planned policies are always decided on the basis of information available at the time, it is natural to use December information from the OECD Economic Outlook publications for the analysis of planned policies.

We follow Cimadomo (2012) and use real time information for all variables in the fiscal policy reaction function. We examine how planned euro area policies (the primary focus of policy makers) have responded to current or expected cyclical conditions in the budgetary year. Discretionary fiscal actions are measured by the cyclically adjusted primary balance (CAPB), i.e. the difference between tax revenues and expenditures, the dynamics of which are determined by the reaction function, specified as

$$
C A P B_{t+1}^{t}=c+\alpha C A P B_{t}^{t}+\beta G A P_{t}^{t}+\gamma D E B T_{t-1}^{t}+\varepsilon_{t}
$$


In equation (1) the variable $\mathrm{CAPB}_{\mathrm{t}+1}^{\mathrm{t}}$ reflects policy actions planned at time $\mathrm{t}$ for the following period, and the term $G A P_{t}^{t}$ is a real time estimate of the current year output gap. The variable $\mathrm{CAPB}_{\mathrm{t}}^{\mathrm{t}}$, is a real time estimate of the current primary balance in period $\mathrm{t}$, so that the parameter $\alpha$ captures fiscal policy inertia (persistence). The real time lagged gross government debt-to-GDP ratio $\left(D E B T_{t-1}^{t}\right)$ indicates the impact of indebtedness on policy decisions. In the forward-looking specification the output gap variable is replaced by the term $G A P_{t+1}^{t}$ (Note 6).

If fiscal policy is counter-cyclical, taxes are raised or expenditures reduced when the output gap is positive and vice versa when the output gap is negative. Thus, the coefficient $\beta$ is positive. Inertia in policy reflects the degree to which policy design emphasizes the long term goals: the larger the estimated coefficient $\alpha$, the greater the long-term orientation. A high degree of persistence in fiscal policy means that the fiscal actions of a given period also limit the options for future fiscal actions, so that there is less leeway for discretionary measures (Note 7). A high coefficient for the debt ratio, $\gamma$, refers to high motivation to reduce indebtedness. Because potential GDP and the output gap measures are subject to considerable uncertainty, we use real GDP growth as an alternative measure of cyclical conditions. In order to conduct a robustness analysis, we estimate the reaction functions using alternatively the current or expected cyclical stance.

There are differences in the conduct of fiscal policy between the countries. For example, the political cycle may impact each country's policy decisions: typically, the pressure for fiscal easing increases before elections. The institutional setup for fiscal policy also affects the policy responses: the tighter the politicians' hands are tied, the more inert the discretionary policy and the less the leeway in policy planning. In panel estimations cross-country differences are taken into account by using the country-specific constants (cross section fixed effects, Note 8).

Our empirical analysis is based on the panel least squares method. When equation (1) is based on expected cyclical conditions, a two-stage least squares method is used. In the forward looking version of equation (1) fiscal policy plans and the expected cyclical situation may be correlated. Thus, there might be feedback effects from planned policy to the output gap (or real GDP growth). Possible simultaneity problems are taken into account in the estimations by employing instrumental variables.

Since the recent crisis was both unexpected and had surprisingly large effects, it is worth investigating fiscal policies separately in the pre-crisis years and crisis-years. In order to distinguish between the two sub-periods, we add a dummy variable to the reaction function. The CRISIS dummy is equal to zero in 1999-2007 and equal to one in 2008-2010 (Note 9). We use the Wald test of coefficient restrictions in order to determine, whether the impact of the crisis on planned policies is statistically significant (Note 10). 
Table 2a. Average Fiscal Plans in the Euro Area, Cyclical Variable: Output Gap

\begin{tabular}{|c|c|c|c|c|c|c|c|c|}
\hline & \multicolumn{4}{|c|}{ OLS } & \multicolumn{4}{|c|}{ IV } \\
\hline & \multicolumn{2}{|c|}{ EMU period } & \multicolumn{2}{|c|}{$\begin{array}{c}\text { Before and during } \\
\text { the crisis }\end{array}$} & \multicolumn{2}{|c|}{ EMU period } & \multicolumn{2}{|c|}{$\begin{array}{c}\text { Before and during } \\
\text { the crisis }\end{array}$} \\
\hline \multirow[t]{2}{*}{$\mathrm{CAPB}_{\mathrm{t}}$} & $0.770^{*}$ & $0.749^{*}$ & & & $0.557^{*}$ & $0.542^{*}$ & & \\
\hline & $(0.039)$ & $(0.039)$ & & & $(0.086)$ & $(0.083)$ & & \\
\hline \multirow[t]{2}{*}{$(1-$ Crisis $) * \mathrm{CAPB}_{\mathrm{t}}$} & & & $0.769^{*}$ & $0.734 *$ & & & $0.640^{*}$ & 0.532 \\
\hline & & & $(0.048)$ & $(0.060)$ & & & $(0.082)$ & $(0.361)$ \\
\hline \multirow[t]{2}{*}{ Crisis* $\mathrm{CAPB}_{\mathrm{t}}$} & & & $0.705^{*}$ & $0.718^{*}$ & & & $0.596^{*}$ & 0.350 \\
\hline & & & $(0.063)$ & $(0.063)$ & & & $(0.098)$ & $(0.314)$ \\
\hline \multirow[t]{2}{*}{$\mathrm{GAP}_{\mathrm{t}+1}$} & & & & & $0.267 *$ & $0.266^{*}$ & & \\
\hline & & & & & $(0.082)$ & $(0.079)$ & & \\
\hline \multirow[t]{2}{*}{$(1-$ Crisis $) * \mathrm{GAP}_{\mathrm{t}+1}$} & & & & & & & 0.121 & -0.338 \\
\hline & & & & & & & $(0.082)$ & $(0.234)$ \\
\hline \multirow[t]{2}{*}{ Crisis* $\mathrm{GAP}_{\mathrm{t}+1}$} & & & & & & & $0.199 *$ & $0.772 *$ \\
\hline & & & & & & & $(0.073)$ & $(0.272)$ \\
\hline \multirow[t]{2}{*}{$\mathrm{GAP}_{\mathrm{t}}$} & 0.044 & 0.058 & & & & & & \\
\hline & $(0.038)$ & $(0.037)$ & & & & & & \\
\hline \multirow[t]{2}{*}{$(1-$ Crisis $) * \mathrm{GAP}_{\mathrm{t}}$} & & & 0.006 & -0.021 & & & & \\
\hline & & & $(0.057)$ & $(0.059)$ & & & & \\
\hline \multirow[t]{2}{*}{ Crisis $^{*} \mathrm{GAP}_{\mathrm{t}}$} & & & 0.069 & $0.110^{*}$ & & & & \\
\hline & & & $(0.044)$ & $(0.049)$ & & & & \\
\hline \multirow[t]{2}{*}{$\operatorname{DEBT}_{\mathrm{t}-1}$} & & $0.023 *$ & & & & 0.020 & & \\
\hline & & $(0.009)$ & & & & $(0.012)$ & & \\
\hline \multirow[t]{2}{*}{$(1-\text { Crisis })^{*} \mathrm{DEBT}_{\mathrm{t}-1}$} & & & & $0.024 *$ & & & & 0.009 \\
\hline & & & & $(0.011)$ & & & & $(0.048)$ \\
\hline \multirow[t]{2}{*}{ Crisis* $^{*}$ DEBT $_{\mathrm{t}-1}$} & & & & $0.027 *$ & & & & 0.043 \\
\hline & & & & $(0.011)$ & & & & $(0.035)$ \\
\hline $\mathrm{R}^{2}$ & 0.919 & 0.924 & 0.921 & 0.926 & 0.881 & 0.883 & 0.907 & 0.799 \\
\hline $\mathrm{D}-\mathrm{W}$ & 2.046 & 2.014 & 2.075 & 1.964 & 1.619 & 1.624 & 1.890 & 1.445 \\
\hline Obs & 114 & 114 & 114 & 114 & 114 & 114 & 114 & 114 \\
\hline \multirow[t]{2}{*}{ Wald test } & & & $\mathrm{F}=1.013$ & $\mathrm{~F}=0.974$ & & & $\mathrm{~F}=0.528$ & $\mathrm{~F}=2.309$ \\
\hline & & & $(0.367)$ & $(0.408)$ & & & $(0.591)$ & $(0.081)$ \\
\hline
\end{tabular}


Table 2b. Average Fiscal Plans in the Euro Area, Cyclical Variable: Real GDP Growth

\begin{tabular}{|c|c|c|c|c|c|c|c|c|}
\hline & \multicolumn{4}{|c|}{ OLS } & \multicolumn{4}{|c|}{ IV } \\
\hline & \multicolumn{2}{|c|}{ EMU period } & \multicolumn{2}{|c|}{$\begin{array}{l}\text { Before and during } \\
\text { the crisis }\end{array}$} & \multicolumn{2}{|c|}{ EMU period } & \multicolumn{2}{|c|}{$\begin{array}{c}\text { Before and during } \\
\text { the crisis }\end{array}$} \\
\hline \multirow[t]{2}{*}{$\mathrm{CAPB}_{\mathrm{t}}$} & $0.725^{*}$ & $0.717^{*}$ & & & $0.650^{*}$ & $0.656^{*}$ & & \\
\hline & $(0.033)$ & $(0.033)$ & & & $(0.066)$ & $(0.066)$ & & \\
\hline \multirow[t]{2}{*}{$\left(1-\right.$ Crisis) ${ }^{*} \mathrm{CAPB}_{\mathrm{t}}$} & & & $0.776^{*}$ & $0.760^{*}$ & & & $0.789^{*}$ & $0.696^{*}$ \\
\hline & & & $(0.039)$ & $(0.053)$ & & & $(0.078)$ & $(0.093)$ \\
\hline \multirow[t]{2}{*}{ Crisis* $^{\text {CAPB }}{ }_{t}$} & & & $0.682 *$ & $0.705^{*}$ & & & $0.797 *$ & $0.780^{*}$ \\
\hline & & & $(0.050)$ & $(0.053)$ & & & $(0.101)$ & $(0.095)$ \\
\hline \multirow[t]{2}{*}{$\mathrm{GDP}_{\mathrm{t}+1}$} & & & & & $0.422^{*}$ & $0.388 *$ & & \\
\hline & & & & & $(0.140)$ & $(0.156)$ & & \\
\hline \multirow[t]{2}{*}{$(1-$ Crisis $) * \mathrm{GDP}_{\mathrm{t}+1}$} & & & & & & & 0.137 & 0.217 \\
\hline & & & & & & & $(0.116)$ & $(0.162)$ \\
\hline \multirow[t]{2}{*}{ Crisis* $\mathrm{GDP}_{\mathrm{t}+1}$} & & & & & & & 0.269 & 0.145 \\
\hline & & & & & & & $(0.174)$ & $(0.195)$ \\
\hline \multirow[t]{2}{*}{$\mathrm{GDP}_{\mathrm{t}}$} & $0.132 *$ & $0.128^{*}$ & & & & & & \\
\hline & $(0.029)$ & $(0.028)$ & & & & & & \\
\hline \multirow[t]{2}{*}{$(1-\text { Crisis })^{*} \mathrm{GDP}_{t}$} & & & 0.046 & 0.051 & & & & \\
\hline & & & $(0.042)$ & $(0.044)$ & & & & \\
\hline \multirow[t]{2}{*}{${\text { Crisis* }{ }^{*}{ }^{2} P_{t}}$} & & & $0.197 *$ & $0.189 *$ & & & & \\
\hline & & & $(0.036)$ & $(0.037)$ & & & & \\
\hline \multirow[t]{2}{*}{$\mathrm{DEBT}_{\mathrm{t}-1}$} & & $0.017^{*}$ & & & & 0.006 & & \\
\hline & & $(0.009)$ & & & & $(0.013)$ & & \\
\hline \multirow[t]{2}{*}{$(1-$ Crisis $) * \mathrm{DEBT}_{\mathrm{t}-1}$} & & & & 0.013 & & & & 0.020 \\
\hline & & & & $(0.010)$ & & & & $(0.015)$ \\
\hline \multirow[t]{2}{*}{ Crisis* $^{\text {DEBT }} \mathrm{t}_{\mathrm{t}-1}$} & & & & 0.013 & & & & 0.021 \\
\hline & & & & $(0.010)$ & & & & $(0.014)$ \\
\hline $\mathrm{R}^{2}$ & 0.932 & 0.935 & 0.938 & 0.939 & 0.883 & 0.889 & 0.912 & 0.915 \\
\hline D-W & 1.802 & 1.830 & 1.819 & 1.814 & 2.282 & 2.288 & 2.194 & 2.133 \\
\hline Obs & 114 & 114 & 114 & 114 & 114 & 114 & 114 & 114 \\
\hline \multirow[t]{2}{*}{ Wald test } & & & $\mathrm{F}=4.434$ & $\mathrm{~F}=2.193$ & & & $\mathrm{~F}=0.302$ & $\mathrm{~F}=0.292$ \\
\hline & & & $(0.014)$ & $(0.094)$ & & & $(0.604)$ & $(0.831)$ \\
\hline
\end{tabular}

Notes: Numbers in parentheses are standard errors. * refers to significance at $5 \%$ level and $* *$ refers to significance at $10 \%$ level. The instruments for the output gap -based IV-equation are the real time current and lagged estimates of real GDP growth. Correspondingly, in the model with real GDP growth, the instruments are real time current and lagged estimates of the output gap. In both cases real time current and lagged estimates of the central government debt-to-GDP ratio are also included in the instrument set. When the lagged debt ratio is included in the reaction function, the second lag of the debt ratio is added to the instrument set. 
Estimation results for the euro area are shown in Tables $2 \mathrm{a}$ and $2 \mathrm{~b}$. At this stage Greece and Ireland are excluded from the panel data set, since exceptional developments in these countries could dominate analysis of average euro area polices. Tables $2 \mathrm{a}$ and $2 \mathrm{~b}$ provide evidence that the reaction function provides a reasonable representation of ex ante policies in the euro area. The explanatory power of the reaction function is quite high, and the estimated coefficients have reasonable magnitudes and signs (with two exceptions, since two negative output gap coefficients are obtained). Policy persistence seems to have been dominating in fiscal planning.

Results for the EMU period without the crisis dummy indicate that policy inertia has been relatively high in the euro area: the estimated persistence coefficients, which are statistically significant at the $5 \%$ level, vary between 0.6 and 0.8 . The cyclical stance seems to also have affected budgetary planning. When the cyclical stance is measured by real GDP growth, all the estimated coefficients, which vary between 0.1 and 0.4 , are statistically significant at the $5 \%$ level. Also the impact of the output gap on budget plans is significant in the forward-looking specification. The data seems not to be that informative about the effects of the debt on budget decisions (Note 11).

Results with the crisis dummy provide separate coefficients for all explanatory variables in the two sub-periods. They indicate that on average the crisis did not substantially affect policy persistence in the euro area, but the cyclical sensitivity on fiscal planning increased slightly during the crisis compared with earlier years. In the pre-crisis years the impact of the cyclical stance is never significant, but we find some evidence of stronger impact during the crisis. When the forward-looking specification of the reaction function is estimated, slightly higher cyclical variable coefficients are mainly obtained than in the other cases. Debt coefficients are almost the same in both sub-periods. The Wald test fails to reject the view that on average the impact of the crisis on euro area ex ante fiscal policies was quite limited (only in one case the Wald test indicate significant policy change at 5\% level).

The analysis of average fiscal policies reported in Tables $2 \mathrm{a}$ and $2 \mathrm{~b}$ provide only a very general view of euro area fiscal policies at the budgetary planning stage. Since economic developments have been very heterogeneous in the euro area - even before the crisis - it is worth exploring the policies pursued by euro area countries in more detail. In particular, it is worth analyzing the cyclicality and persistence of fiscal policies over the pre-crisis and crisis period to see if differences emerge between periphery countries and other countries. The estimation results for the two country groups are summarized in Table 3. In order to avoid possible problems with the choice of instruments and small samples, we consider only specifications based on current cyclical conditions.

Table 3 reveals interesting differences in budgetary planning across the two country groups. It provides evidence that in the pre-crisis years long term orientation of fiscal plans was quite high in both country groups (the estimated persistence coefficients $\alpha$ are $0.7-0.8$ ), but only the periphery countries clearly gave up their long term goals during the crisis (the persistence coefficients $\alpha$ are 0.1 and 0.2 ). The reaction of policies to the economic cycle has been counter-cyclical in both country groups, but in both sub-periods the policy response seems to 
have been systematically higher in the periphery countries (as higher estimated $\beta$-coefficients are always obtained). During the crisis the impact of the cyclical stance on fiscal policies has always been significant, but in the pre-crisis years it is never significant for the group of other countries. Interestingly, for the periphery countries the estimated debt coefficients are always significant and higher than for the other group (Note 12).

Table 3. Planned Fiscal Policy Estimates for Two Country Groups

\begin{tabular}{|c|c|c|c|c|}
\hline & $\begin{array}{l}\text { Periphery } \\
\text { countries }\end{array}$ & $\begin{array}{c}\text { Other } \\
\text { countries }\end{array}$ & $\begin{array}{l}\text { Periphery } \\
\text { countries }\end{array}$ & $\begin{array}{c}\text { Other } \\
\text { countries }\end{array}$ \\
\hline \multirow[t]{2}{*}{$\left(1-\right.$ Crisis) $* \mathrm{CAPB}_{\mathrm{t}}$} & $0.774 *$ & $0.731 *$ & $0.731^{*}$ & $0.766^{*}$ \\
\hline & $(0.088)$ & $(0.078)$ & $(0.076)$ & $(0.064)$ \\
\hline \multirow[t]{2}{*}{ Crisis* CAPB $_{t}$} & 0.111 & $0.805^{*}$ & $0.197 *$ & $0.762 *$ \\
\hline & $(0.085)$ & $(0.095)$ & $(0.056)$ & $(0.079)$ \\
\hline \multirow[t]{2}{*}{$(1-\text { Crisis })^{*} \mathrm{GAP}_{\mathrm{t}}$} & 0.053 & 0.002 & & \\
\hline & $(0.124)$ & $(0.068)$ & & \\
\hline \multirow[t]{2}{*}{ Crisis $^{*} \mathrm{GAP}_{\mathrm{t}}$} & $0.562 *$ & $0.098^{* *}$ & & \\
\hline & $(0.169)$ & $(0.051)$ & & \\
\hline \multirow[t]{2}{*}{$(1-$ Crisis $) * \mathrm{GDP}_{\mathrm{t}}$} & & & $0.239 *$ & 0.037 \\
\hline & & & $(0.103)$ & $(0.046)$ \\
\hline \multirow[t]{2}{*}{ Crisis $^{*} \mathrm{GDP}_{\mathrm{t}}$} & & & $0.484^{*}$ & $0.183^{*}$ \\
\hline & & & $(0.091)$ & $(0.038)$ \\
\hline \multirow[t]{2}{*}{$(1-C r i s i s)^{*} \mathrm{DEBT}_{\mathrm{t}-1}$} & $0.061^{*}$ & $0.031 *$ & $0.040^{*}$ & 0.016 \\
\hline & $(0.022)$ & $(0.015)$ & $(0.019)$ & $(0.013)$ \\
\hline \multirow[t]{2}{*}{ Crisis* $^{*} \mathrm{DEBT}_{\mathrm{t}-1}$} & $0.083^{*}$ & $0.030^{*}$ & $0.051 *$ & 0.013 \\
\hline & $(0.023)$ & $(0.015)$ & $(0.018)$ & $(0.013)$ \\
\hline $\mathrm{R}^{2}$ & 0.848 & 0.939 & 0.894 & 0.953 \\
\hline $\mathrm{D}-\mathrm{W}$ & 1.805 & 1.964 & 1.609 & 1.827 \\
\hline Obs & 59 & 78 & 59 & 78 \\
\hline \multirow[t]{2}{*}{ Wald test } & $F=10.087$ & $\mathrm{~F}=0.739$ & $F=12.766$ & $\mathrm{~F}=2.062$ \\
\hline & $(0.000)$ & $(0.533)$ & $(0.000)$ & $(0.114)$ \\
\hline
\end{tabular}

Overall, the results in Table 3 suggest that the periphery countries changed their policies substantially at the planning stage in the crisis years. In response to the deep recession, the periphery countries had to react strongly to weakening economic situation and rising debt ratios at the cost of long term policy goals. In contrast, the other countries did not change their policies substantially at the planning stage. The Wald test confirms a clear difference in planned policies between the two country groups: with both cyclical variables the test indicates that the crisis changed ex ante fiscal planning significantly only in the periphery countries.

\subsection{Policy changes during budget implementation}

Only the periphery countries seem to have changed ex ante fiscal policies during the crisis. However, it is not unreasonable to interpret the policy debate in the euro area as indicating 
that all euro area countries adjusted their policies to the deep recession. Hence, in the following we analyze real time fiscal policy decisions in more detail. When using real time information we are able to capture the economic situation confronting policy makers when previously planned policy measures are implemented. If the fiscal situation or cyclical conditions have changed substantially from the view prevailing at the time fiscal plans were made and/or data revisions are substantial, fiscal policy is adjusted (i.e. new decisions are made). In the analysis of policy changes in the implementation stage, we use both June and December information from the OECD Economic Outlook publications.

The term $\mathrm{CAPB}_{\mathrm{t}}^{\mathrm{t}, \mathrm{t}-1}\left(=\mathrm{CAPB}_{\mathrm{t}}^{\mathrm{t}}-\mathrm{CAPB}_{\mathrm{t}}^{\mathrm{t}-1}\right)$ is the difference between the real time current-year estimate of the primary balance and the corresponding last-year forecast. Correspondingly, we define the variable $\mathrm{CAPB}_{t-1}^{\mathrm{t}, \mathrm{t}-1}\left(=\mathrm{CAPB}_{\mathrm{t}-1}^{\mathrm{t}}-\mathrm{CAPB}_{\mathrm{t}-1}^{\mathrm{t}-1}\right)$ as the difference between the real time view of last year's primary balance and the corresponding real time estimate, as assessed last year. We also measure revision of the cyclical situation at the interim stage of the budgetary year as $\mathrm{GAP}_{t}^{\mathrm{tj}, \mathrm{t}-1}=\mathrm{GAP}_{\mathrm{t}}^{\mathrm{tj}}-\mathrm{GAP}_{\mathrm{t}}^{\mathrm{t}-1}$, i.e. the difference between a real time mid-year estimate of the current year output gap and the corresponding expected output gap at the time of fiscal planning. The mid-year real time estimate is based on June information from the OECD.

We follow Beetsma and Giuliodori (2010) and estimate the regression

$$
C A P B_{t}^{t, t-1}=c+\varphi C A P B_{t-1}^{t, t-1}+\rho C A P B_{t}^{t-1}+\theta G A P_{t}^{t j, t-1}+\mu_{t}
$$

In equation (2) the adjustment to discretionary policy during the budgetary year is explained by the three factors which relate real time information at the time of fiscal planning to real time information at the time of budget implementation. During the implementation stage, fiscal policy is adjusted to new information related to the previous year's primary balance, last year's fiscal plans and new information on cyclical conditions. The term $\mathrm{CAPB}_{\mathrm{t}}^{\mathrm{t}-1}$ refers to the budgetary process effect on fiscal adjustment. The budgetary planning stage and implementation stage are closely linked, since it is clear that large forecast errors in the planning state increase the need to adjust policy in the course of the budgetary year.

Equation (2) obviates potential endogeneity problems, since we use real time mid-year estimates of the output gap. It is reasonable to assume that it takes at least a half year before error in the fiscal stance has an impact on the output gap. Therefore, equation (2) can be estimated using OLS method. Again, the estimations include country-specific constants and two alternative measures of cyclical conditions. Since we are focusing on the impacts of the recent crisis, only estimations including the crisis dummy and the corresponding Wald test results are summarized in Table 4. Again, we investigate the whole euro area and the two country groups separately (Note 13). 
Table 4. Fiscal Responses during Budget Implementation Stage

\begin{tabular}{|c|c|c|c|c|c|c|}
\hline & \multicolumn{3}{|c|}{ Output gap } & \multicolumn{3}{|c|}{ Real GDP growth } \\
\hline & $\begin{array}{l}\text { Average } \\
\text { policies }\end{array}$ & $\begin{array}{l}\text { Periphery } \\
\text { countries }\end{array}$ & $\begin{array}{l}\text { Other } \\
\text { countries }\end{array}$ & $\begin{array}{l}\text { Average } \\
\text { policies }\end{array}$ & $\begin{array}{l}\text { Periphery } \\
\text { countries }\end{array}$ & $\begin{array}{l}\text { Other } \\
\text { countries }\end{array}$ \\
\hline$(1-C R I S I S) \times C A P B B_{t-1}^{t, t-1}$ & $\begin{array}{l}0.751^{*} \\
(0.107)\end{array}$ & $\begin{array}{l}1.047 * \\
(0.285)\end{array}$ & $\begin{array}{l}0.753 * \\
(0.108)\end{array}$ & $\begin{array}{l}0.684 * \\
(0.108)\end{array}$ & $\begin{array}{l}1.085^{*} \\
(0.351)\end{array}$ & $\begin{array}{l}0.740^{*} \\
(0.116)\end{array}$ \\
\hline$C R I S I S \times C A P B_{t-1}^{t, t-1}$ & $\begin{array}{l}1.267 * \\
(0.159)\end{array}$ & $\begin{array}{l}-0.115 \\
(0.335)\end{array}$ & $\begin{array}{l}1.402 * \\
(0.219)\end{array}$ & $\begin{array}{l}1.014 * \\
(0.161)\end{array}$ & $\begin{array}{l}1.040 * \\
(0.443)\end{array}$ & $\begin{array}{l}1.069^{*} \\
(0.218)\end{array}$ \\
\hline$(1-C R I S I S) \times C A P B_{t}^{t-1}$ & $\begin{array}{l}-0.105 \\
(0.054)\end{array}$ & $\begin{array}{l}0.040 \\
(0.129)\end{array}$ & $\begin{array}{l}-0.109 * \\
(0.054)\end{array}$ & $\begin{array}{l}-0.066 \\
(0.050)\end{array}$ & $\begin{array}{l}0.150 \\
(0.165)\end{array}$ & $\begin{array}{l}-0.061 \\
(0.052)\end{array}$ \\
\hline$C R I S I S \times C A P B_{t}^{t-1}$ & $\begin{array}{l}-0.318^{*} \\
(0.075)\end{array}$ & $\begin{array}{l}0.724 * \\
(0.165)\end{array}$ & $\begin{array}{l}-0.239 * \\
(0.079)\end{array}$ & $\begin{array}{l}-0.226^{*} \\
(0.076)\end{array}$ & $\begin{array}{l}0.383 \\
(0.205)\end{array}$ & $\begin{array}{l}-0.164 * \\
(0.080)\end{array}$ \\
\hline$(1-C R I S I S) \times G A P_{t}^{t j, t-1}$ & $\begin{array}{l}0.079 \\
(0.141)\end{array}$ & $\begin{array}{l}0.127 \\
(0.304)\end{array}$ & $\begin{array}{l}-0.057 \\
(0.145)\end{array}$ & & & \\
\hline$C R I S I S \times G A P_{t}^{t j, t-1}$ & $\begin{array}{l}0.410^{*} \\
(0.078)\end{array}$ & $\begin{array}{l}2.345^{*} \\
(0.393)\end{array}$ & $\begin{array}{l}0.396^{*} \\
(0.070)\end{array}$ & & & \\
\hline$(1-C R I S I S) \times G D P_{t}^{t j, t-1}$ & & & & $\begin{array}{l}0.197 \\
(0.131)\end{array}$ & $\begin{array}{l}0.793 \\
(0.504)\end{array}$ & $\begin{array}{l}-0.079 \\
(0.146)\end{array}$ \\
\hline$C R I S I S \times G D P_{t}^{t j, t-1}$ & & & & $\begin{array}{l}0.411 * \\
(0.066)\end{array}$ & $\begin{array}{l}0.076 \\
(0.259)\end{array}$ & $\begin{array}{l}0.382 * \\
(0.061)\end{array}$ \\
\hline $\mathrm{R}^{2}$ & 0.698 & 0.663 & 0.747 & 0.727 & 0.434 & 0.764 \\
\hline D-W & 2.004 & 2.191 & 2.325 & 2.130 & 1.915 & 2.429 \\
\hline Obs & 113 & 58 & 77 & 113 & 58 & 77 \\
\hline Wald test & $\begin{array}{l}F=8.976 \\
(0.000)\end{array}$ & $\begin{array}{l}F=8.876 \\
(0.000)\end{array}$ & $\begin{array}{l}F=8.890 \\
(0.000)\end{array}$ & $\begin{array}{l}F=4.924 \\
(0.003)\end{array}$ & $\begin{array}{l}F=1.071 \\
(0.371)\end{array}$ & $\begin{array}{l}F=6.659 \\
(0.001)\end{array}$ \\
\hline
\end{tabular}

Numbers in parentheses are standard errors. * refers to significance at $5 \%$ level.

The results for the whole euro area indicate that on average the crisis had a clear impact of planned budgets during budget implementation. The estimated $\varphi$ coefficient indicate that the base effect seems to have been important in both sub-periods, but probably due to huge data revisions in recent years, the estimated coefficients are higher during the crisis than in the earlier years. The budgetary process effect (coefficient $\rho$ ) had no impact on policy changes prior to the recession, when fiscal policy frameworks were quite stable in the euro area. This effect became important during the crisis years, however. Also the cyclical effect has only been important during the crisis (higher and significant $\theta$ coefficients are obtained for the second sub-period). The growing importance of cyclical effect is plausible, since during the crisis huge forecast errors made at the time of budgetary planning.

Policy changes during budget implementation seem to have been clearly different in the two country groups. The base effect was significant for both country groups before the crisis. In the case of periphery countries the importance of this effect decreased in the second sub-period, but the estimated coefficient is almost unchanged for the other countries. For both country groups the budgetary process effect seems to have been more important during the crisis than in the earlier years. It is worth noting that the real time information of the output 
gap has contributed significantly to policy changes, especially in the case of the periphery countries. When the specification is based on real GDP growth, the cyclical effect is not important for the periphery countries.

The Wald test suggests that fiscal policy adjustment changed significantly during the crisis in both country groups (with only real GDP growth we get the opposite result for the periphery countries). Analysis of policy changes confirm the result obtained in the previous section: the importance of the cyclical variables for discretionary policy decisions increased during the crisis.

All in all, the empirical analysis presented above indicates that during the monetary union (EMU) euro area planned fiscal policies have been long-term oriented and counter-cyclical. In the implementation stages fiscal plans have been adjusted in response to unexpected macroeconomic developments. We provide evidence that the crisis had a clear impact on discretionary policies due to heightened uncertainty. The periphery countries adjusted their policies clearly in the budgetary planning stage. Other countries reacted to the crisis mainly during budget implementation.

The crisis seems to have emphasized the response of policies to the economic cycle. It is very challenging to assess the cyclical stance in real time. During a deep recession real GDP growth and the output gap can give very different pictures of the cyclical situation for fiscal policy purposes. For instance, looking at GDP growth, one may see the recession as a collapse in a single year whereas the output gap may indicate a long-lasting downswing (as long as output remains below potential). Real GDP growth seems not to point to a long-term collapse of economic activity in the crisis years. In contrast, permanently negative output gap indicates that post-crisis growth does not accelerate sufficiently fast to close the output gap. (see Figures in Appendix 1).

\subsection{Related studies}

Our analysis is related to several recent studies based on fiscal policy reaction functions and real time information. Cimadomo (2012), for instance, analyses fiscal policy in 19 industrial countries 1994-2006. The results of that study show that, based on final data, fiscal policy in OECD countries was relatively pro-cyclical, whereas it was counter-cyclical from the perspective of real time data. Using European Commission data, Pina (2009) also shows that, based on real time data, fiscal policy in $15 \mathrm{EU}$ countries has generally been more counter-cyclical than is suggested by the final data. Beetsma et al. (2009) explore fiscal plans and their implementation in the EU. They find that implemented budgetary adjustment falls systematically short of planned adjustment and this shortfall increases with the forecast horizon. They also argue that strong national fiscal institutions contribute to ambitious fiscal plans and effective implementation. Fiscal planning and budget implementation stages in the Netherlands are analyzed in Beetsma et al. (2010). Using real time data, which cover the period 1958-2009, the study finds evidence that institutional factors are important for understanding the objectives of fiscal planning. Beetsma and Giuliodori (2010) study fiscal plans and their implementation in OECD countries in 1995-2006. Using real time data they find that empirical identification of the fiscal planning and implementation stages is crucial. 
They provide evidence that fiscal plans have been acyclical in EU countries and counter-cyclical in the other OECD countries. In the implementation stage, the response of EU countries to unexpected changes in the output gap has been pro-cyclical. In contrast, in other OECD countries the response has been acyclical.

\section{Concluding Remarks}

We have identified and provided an analysis of discretionary fiscal policies in the euro area countries since the late 1990s. In addition to the average policies, two country groups, defined on the basis of recent developments in government bond yields, were examined separately. Both fiscal plans for budgetary years and policy changes during the budget implementation (in the course of the budgetary year) were investigated using real time data constructed from the June and December issues of the OECD's Economic Outlook. The main focus of this study was on fiscal adjustment to the recent financial and economic crisis.

The results indicate that, during the crisis, forecast errors and statistical revisions in the euro area data were considerably larger than before. Cross-country differences in forecast errors and statistical revisions have been significant across the euro area countries.

The results also suggest that during the time of monetary union (EMU) euro area planned fiscal policies have basically been long-term oriented and counter-cyclical. Moreover, in the implementation stages fiscal plans have been updated and new policy decisions have been made in response to unexpected economic developments. The crisis had a clear impact on euro area fiscal policies. The periphery countries adjusted their policies clearly in the budgetary planning stage. Other countries reacted to the crisis mainly during budget implementation.

Fiscal adjustment after the budgetary planning stage may have negative effects on the economy. Economic agents form their expectations on the basis of fiscal plans. If, however, plans are notably adjusted in the implementation stage, it might be costly for economic agents to change their behavior accordingly.

The results indicate that in the EMU period also the periphery countries have conducted quite responsible policies with respect to cyclical situation. However, the insufficient role of indebtedness considerations in budgetary planning has clearly contributed to the observed debt accumulation. Also, cumulated macroeconomic imbalances have increased indebtedness. Overall, our results indicate that real time uncertainty and data revisions affect budget decisions substantially. Therefore, real time monitoring of budgeting processes and multi-annual fiscal planning are crucial in good fiscal governance.

\section{Acknowledgement}

The views expressed are those of the author and do not necessarily reflect the views of the Bank of Finland. The earlier version of this paper was titled "Real time analysis of euro area 
fiscal policies: adjustment to the crisis". Useful comments received in the XXXIV Annual Meeting of Finnish Society for Economic Research (Vaasa, February 2012) and in International Atlantic Economic Conference (Istanbul, March 2012) are gratefully acknowledged. We thank participants in CEUS Workshop on 'Challenges to Stability in the Euro Area' (Vallendar/Koblenz, May 2012) for valuable discussion. We also thank comments received in Ljubljana (June 2012) in the workshop 'Reforming Finance: Balancing Domestic and International Agendas'. Thanks are due to Helvi Kinnunen, Jouko Vilmunen and Matti Virén for useful comments and to Reijo Siiskonen and Tarja Yrjölä for research assistance.

\section{References}

Afonso, A., Agnello, L., \& Furceri, D. (2010). Fiscal policy responsiveness, persistence, and discretion. Public Choice, 145, 503-530. http://dx.doi.org/10.1007/s11127-009-9577-x

Beetsma, R., \& Giuliodori, M. (2010). Fiscal Adjustment to Cyclical Developments in the OECD: An Empirical Analysis Based on Real-Time Data. Oxford Economic Papers, 62, 419-441. http://dx.doi.org/10.1093/oep/gpp039

Beetsma, R., Bluhm, B., Giuliodori, M., \& Wierts, P. (2011). From First-Release to Ex-Post Fiscal Data: Exploring the Sources of Revisions Errors in the EU. CEPR Discussion Paper No. 8413.

Beetsma, R., Giuliodori, M., \& Wierts P. (2009). Planning to cheat: EU fiscal policy in real time. Economic Policy, 24, 753-804. http://dx.doi.org/10.1111/j.1468-0327.2009.00230.x

Beetsma, R., Giuliodori, M., Walschot, M., \& Wierts, P. (2010). Fifty years of Fiscal Planning and Implementation in the Netherlands. CEPR Discussion Paper No. 7969.

Beffy, P. O., Ollivaud, P., Richardson P., \& Sedillot, F. (2006). New OECD Methods for Supply-Side and Medium-term Assessments: A Capital Services Approach, OECD Economics Department Working Papers, No. 482. http://dx.doi.org/10.1787/628752675863

Candelon, B., Muysken, J., \& Vermeulen, R. (2010). Fiscal policy and monetary integration in Europe: an update. Oxford Economic Papers, 62, 323-349. http://dx.doi.org/10.1093/oep/gpp017

Cimadomo, J. (2011a). Fiscal Stimulus and Challenges Ahead: Views on the Euro Area. The Economic Society of Australia Economic Papers, 30, 23-28. http://dx.doi.org/10.1111/j.1759-3441.2011.00110.x

Cimadomo, J. (2011b). Real-Time Data and Fiscal Policy Analysis: A Survey of the Literature. Federal Reserve Bank of Philadelphia Working Paper, No. 25.

Cimadomo, J. (2012). Fiscal Policy in Real Time. Scandinavian Journal of Economics, 114(2), 440-465. http://dx.doi.org/10.1111/j.1467-9442.2012.01697.x 
de Castro, F., Pérez, J. J., \& Rodríguez-Vives, M. (2013). Fiscal data revisions in Europe. Journal of Money, Credit and Banking, 45, 1187-1209. http://dx.doi.org/10.1111/jmcb.12049

European Commission. (2004). The Pro-Cyclicality of Fiscal Policy in EMU. Quarterly Report on the Euro Area, Vol. 3.

Frankel, J. A., \& Schreger, J. (2012). Over-optimistic Official Forecasts in the Eurozone and Fiscal Rules. NBER Working Paper No. 18283.

Galí, J., \& Perotti, R. (2003). Fiscal policy and monetary integration in Europe. Economic Policy, 18, 533-572. http://dx.doi.org/10.1111/1468-0327.00115_1

Golinelli, R., \& Momigliano, S. (2006). Real-time Determinants of Fiscal Policies in the Euro Area. Journal of Policy Modeling, 28, 943-964. http://dx.doi.org/10.1016/j.jpolmod.2006.08.001

Golinelli, R., \& Momigliano, S. (2009). The Cyclical Reaction of Fiscal Policies in the Euro Area: The Role of Modelling Choices and Data Vintages. Fiscal Studies, 30(1), 39-72. http://dx.doi.org/10.1111/j.1475-5890.2009.00089.x

Hughes Hallett, A., Kattai, R., \& Lewis, J. (2012). How Reliable Are Cyclically Adjusted Budget Balances In Real Time? Contemporary Economic Policy, Western Economic Association International, $30(1)$, 75-92. http://dx.doi.org/10.1111/j.1465-7287.2011.00250.x

Lane, P. R. (2003a). Business Cycles and Macroeconomic Policy in Emerging Market Economies. International Finance, 6, 89-108.

Lane, P. R. (2003b). The Cyclical Behaviour of Fiscal Policy: Evidence from the OECD. Journal of Public Economics, 87, 2661-2675. http://dx.doi.org/10.1016/S0047-2727(02)00075-0

OECD (2009). Beyond the crisis: medium-term challenges relating to potential output, unemployment and fiscal positions. Chapter 4 of OECD Economic Outlook no. 85. http://dx.doi.org/10.1787/eco_outlook-v2009-1-en

Pina, A. (2009). Elusive Counter-Cyclicality and Deliberate Opportunism? Fiscal Policy from Plans to Final Outcomes, Banco de Portugal Working Paper No. 6.

Staehr, K. (2008). Fiscal policies and business cycles in an enlarged euro area. Economic Systems, 32, 46-69. http://dx.doi.org/10.1016/j.ecosys.2007.06.007

van Riet, A. (ed.) (2010). Euro area fiscal policies and the crisis. European Central Bank Occasional Paper No. 109. 


\section{Appendix}

Appendix 1. Real time estimates for euro area countries

France

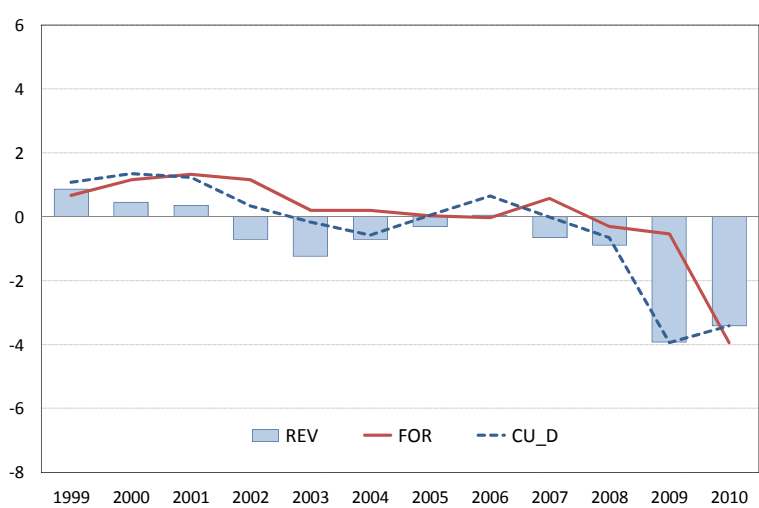

Italy

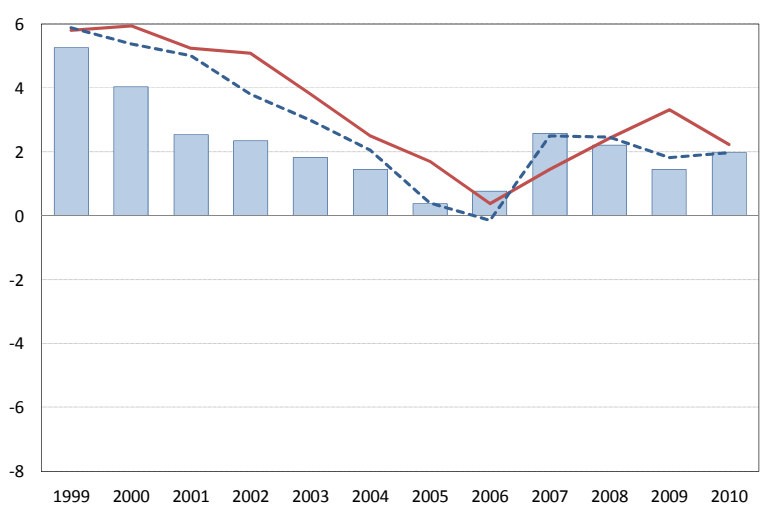

Germany

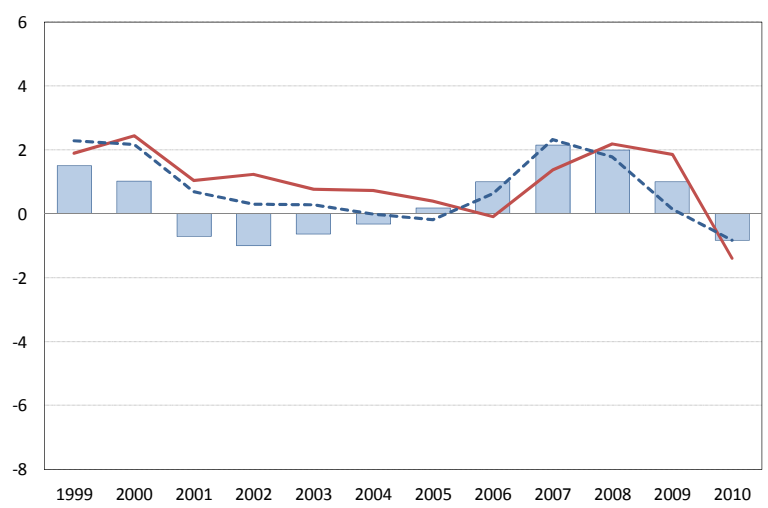

Spain

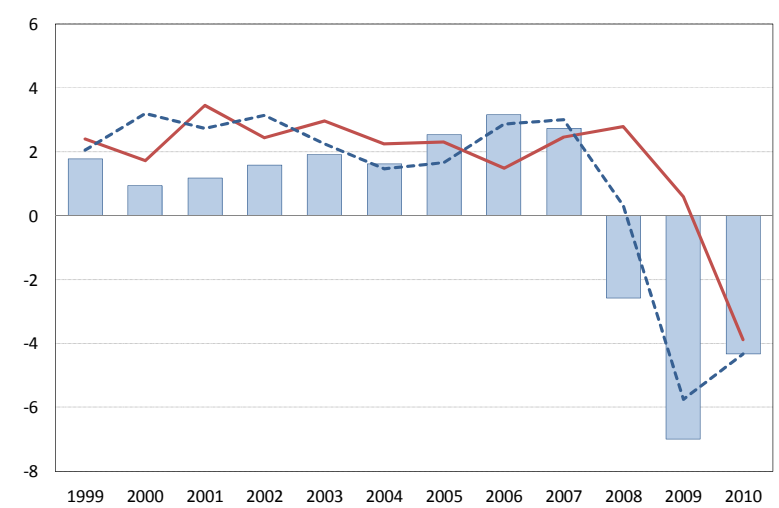

Figure 1. Real time estimates of cyclically adjusted primary balances 
France

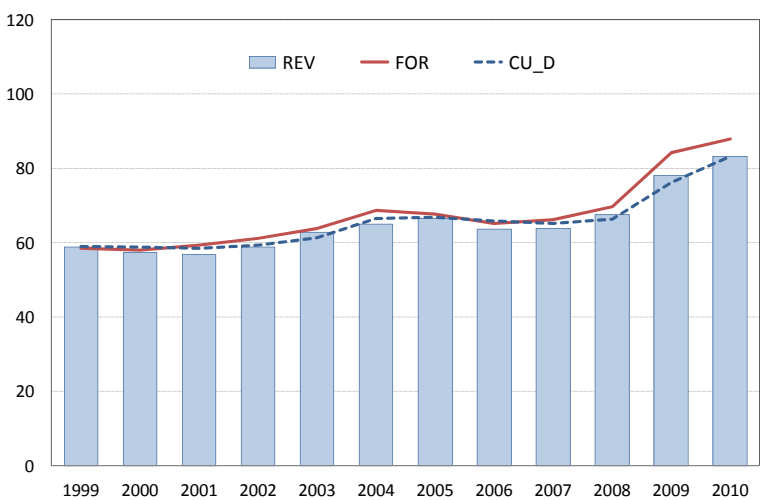

Italy

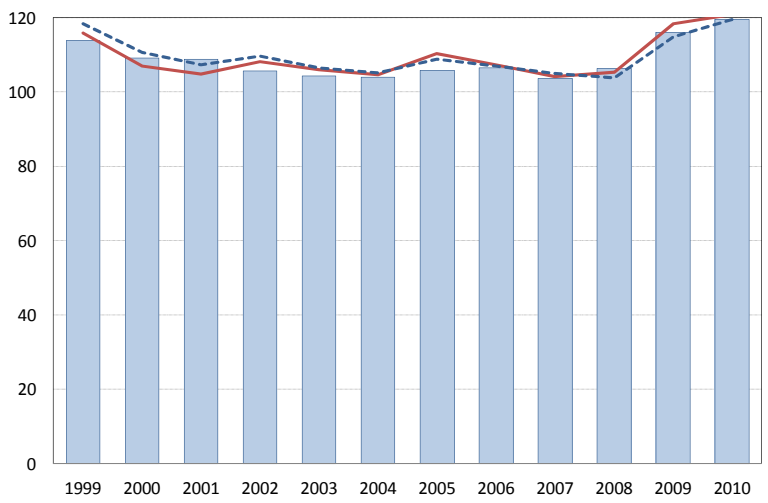

\section{Germany}

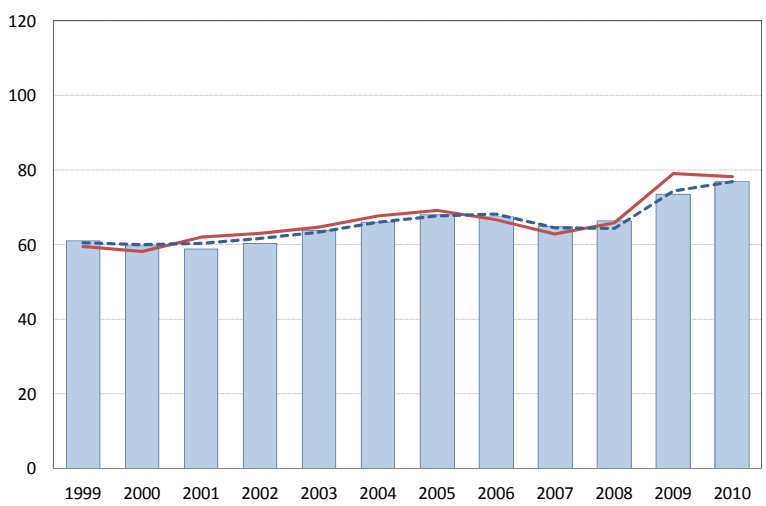

Spain

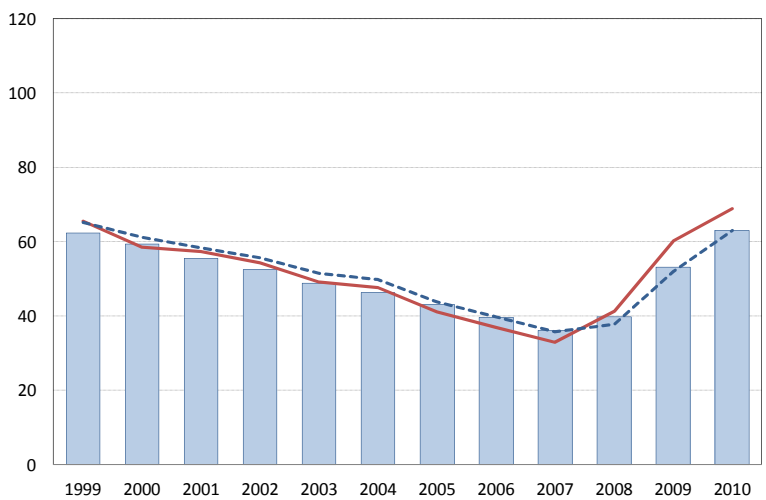

Figure 2. Real time estimates of government debt 


\section{France}

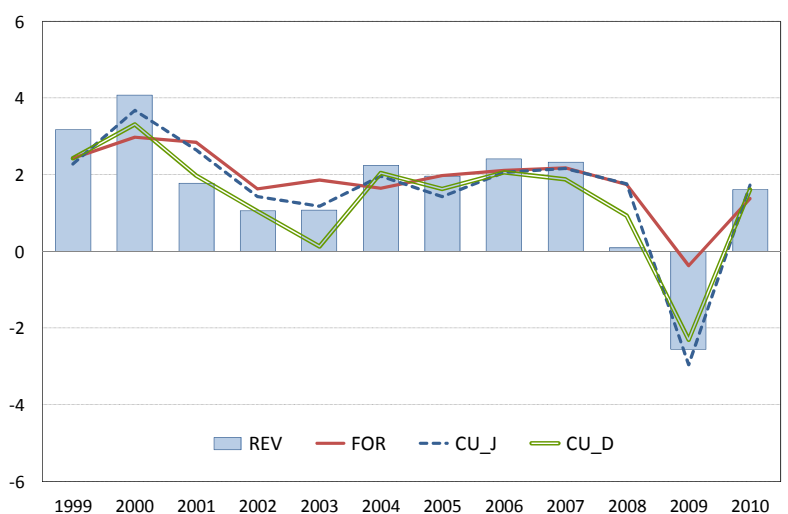

Italy

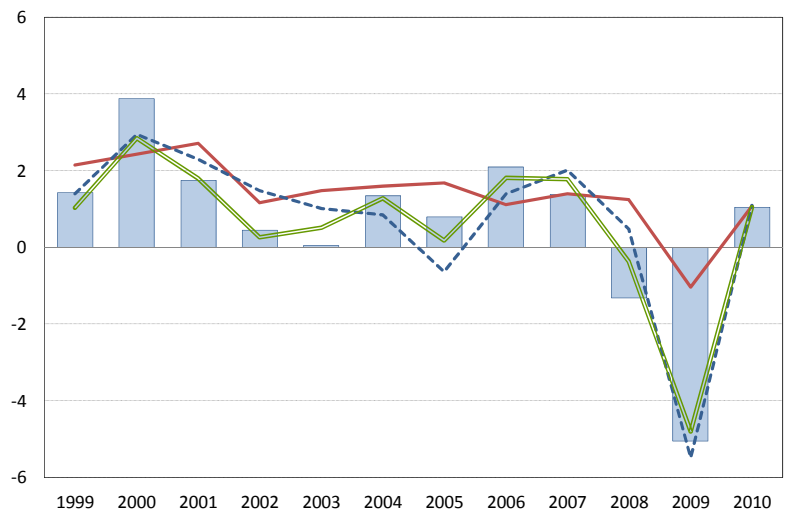

Germany

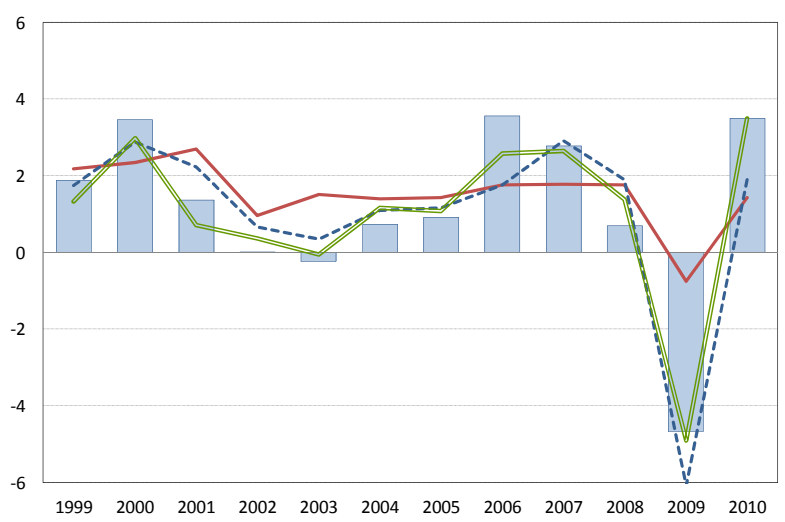

Spain

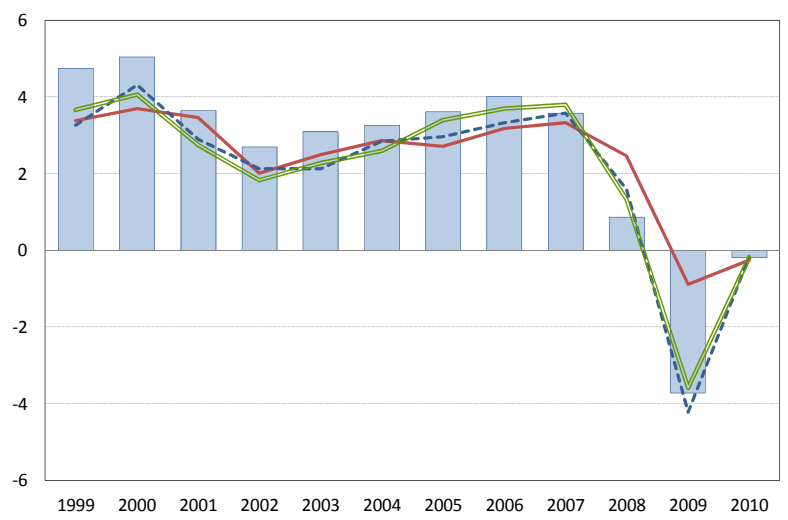

Figure 3. Real time estimates of real GDP growth 


\section{France}

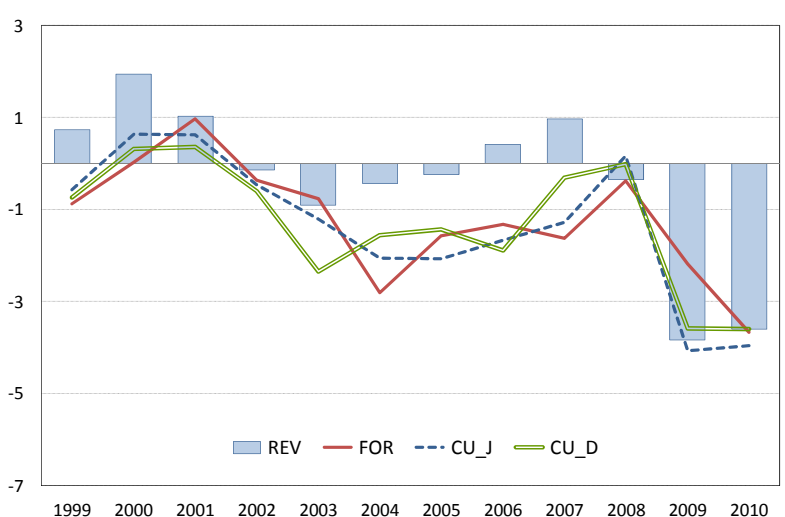
Italy

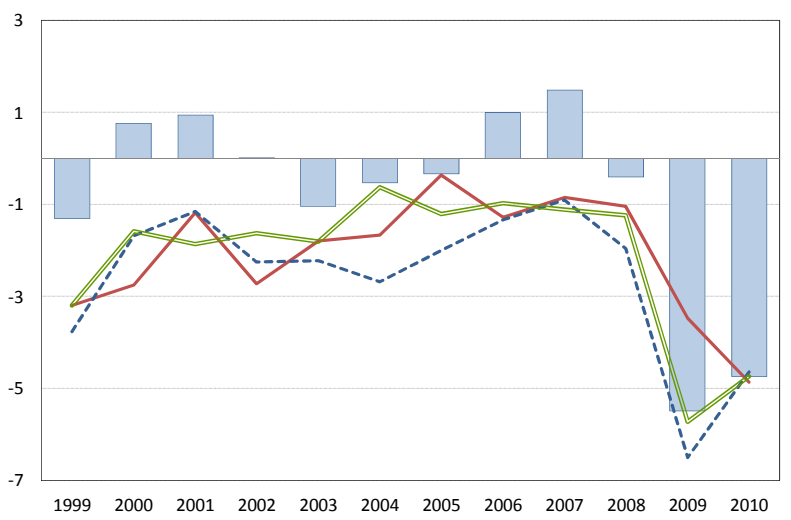

Germany

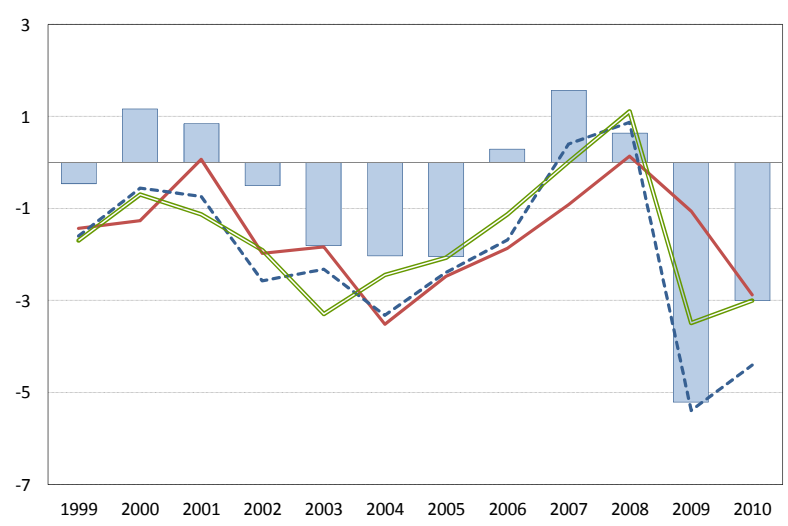
Spain

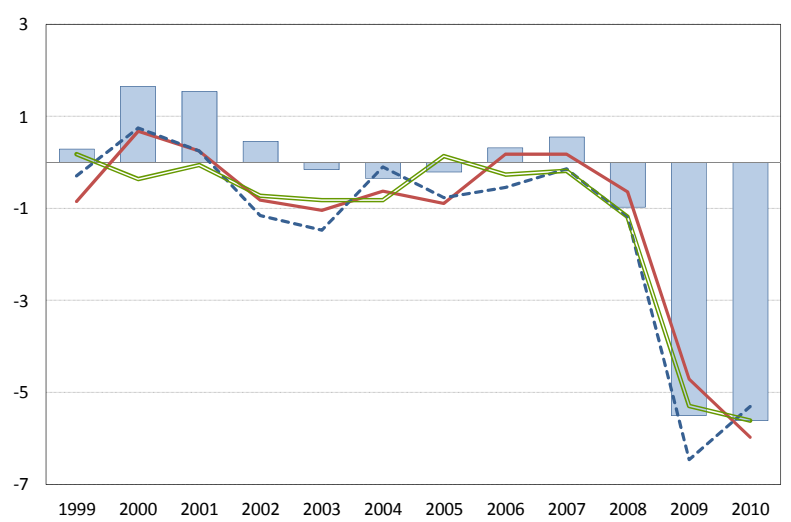

Figure 4. Real time estimates of output gap 
Appendix 2. Real time assessments for year 2009

France

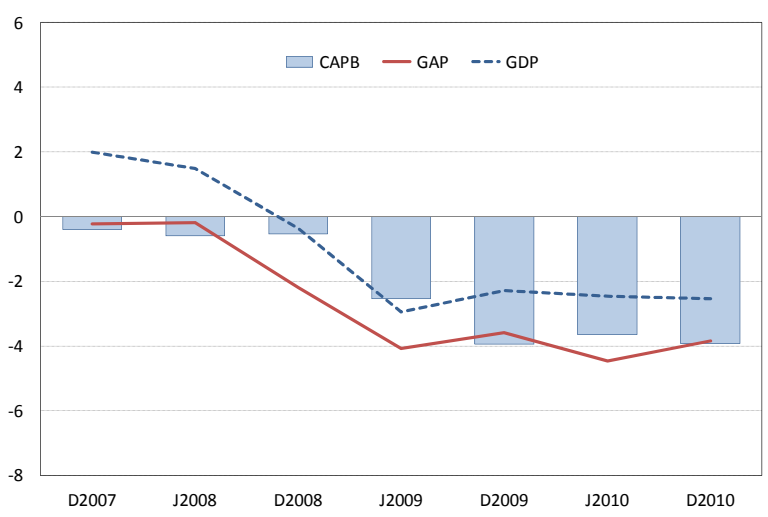

Italy

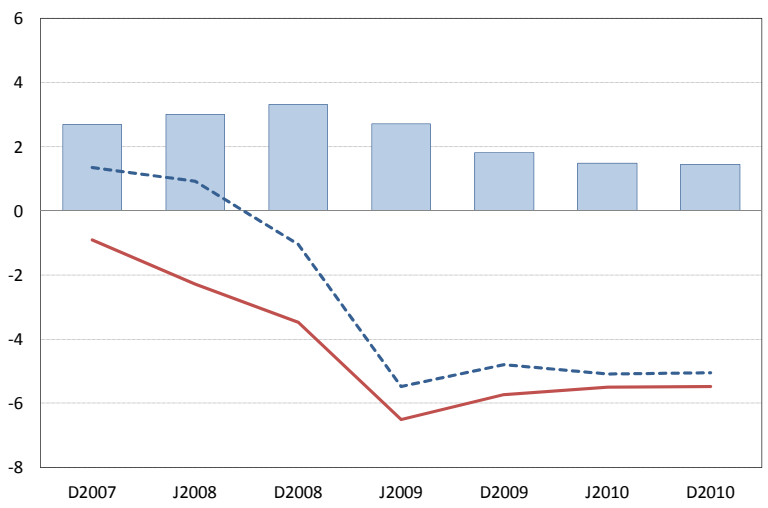

Germany

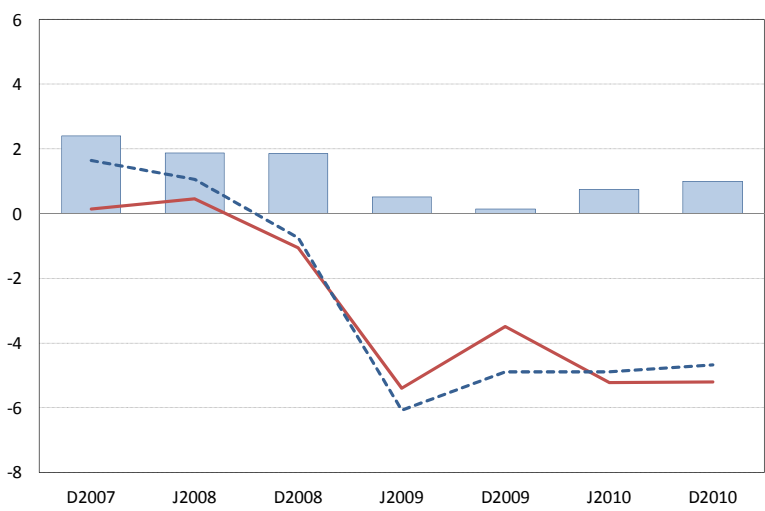

Spain

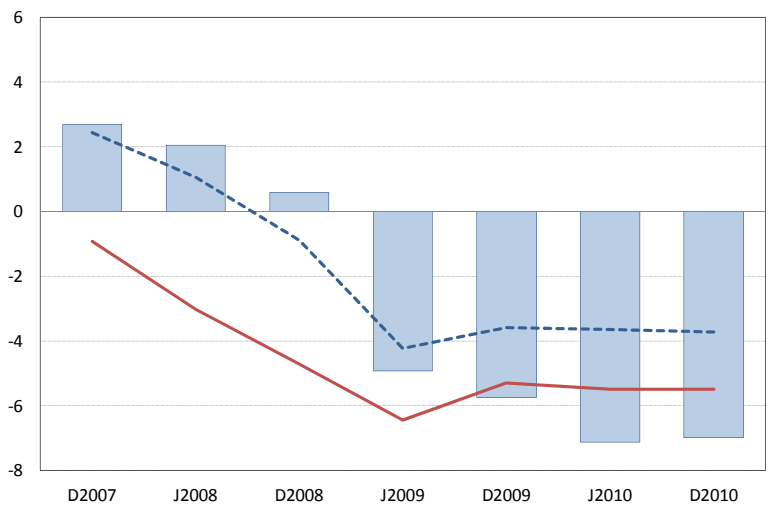

Note: The first three observations are forecasts made in the end of 2007 (D2007) mid-2008 (J2008) and in the end of 2008 (D2008). Real time current-year estimates were published in June 2009 (J2009) and December 2009 (D2009). The last two observations are data revisions, made in June 2010 (J2010) and December 2010 (D2010).

\section{Endnotes}

Note 1. For more on euro area fiscal policies during the crisis, see eg van Riet (ed.) (2010). Future challenges of euro area fiscal policies are discussed in Cimadomo (2011a).

Note 2. To estimate the discretionary component of fiscal policy, one must eliminate from the government financial balance the business-cycle effects and other effects not due to current fiscal actions, such as changes in interest rates and the effects of prior developments in debts and receivables.

Note 3. For details of the OECD's production-function-based methodology, see Beffy et al. (2006) and OECD (2009): Chapter 4 in Economic Outlook No. 85.

Note 4. The most recent years' data are still subject to revision. 
Note 5. For a survey of real time fiscal policy literature, see Cimadomo (2011b). See Golinelli and Momigliano (2009) for a survey of recent empirical literature concerning to cyclical response of fiscal policies in the euro area.

Note 6. Other factors influencing fiscal policy plans can also be taken into account by in the reaction function. For example, variables related to demographics (Beetsma and Giuliodori 2010) or to elections (Golinelli and Momigliano 2006) are typical additional explanatory variables in reaction functions.

Note 7. Afonso et. al. (2010) find a negative correlation between degrees of discretionary leeway and persistence, which supports this view.

Note 8. As Pina (2009) has argued, it is not necessary reasonable use time fixed effects in fiscal policy reaction functions. Since these effects capture fiscal responses to common shocks, they may change the interpretation of the cyclicality parameter $\beta$.

Note 9. Galí and Perotti (2003) estimate a similar equation based on a dummy variable in order to examine the significance of the Maastricht Treaty for fiscal policy. Dummy variables are also used by Beetsma and Giuliodori (2010). In that study OECD countries are divided into EU members and other countries in an analysis of fiscal policy. Staerh (2008) divides his data set into Central and Eastern European countries and examines the cycle-sensitivity of fiscal policy. Candelon et. al. (2010) use a similar approach in studying the stability of fiscal rules for EMU countries before and after the Maastricht Treaty.

Note 10. More specifically, we test the null hypothesis, according to which all estimated coefficients are the same in the pre-crisis and crisis years.

Note 11. If reaction functions in Table 2 are estimated without country-specific constants, the results are almost unchanged.

Note 12. In order to make sensitivity analysis for fiscal policies in the planning stage, we excluded one country at a time from both country groups in estimations reported in Table 3. Overall, the results (not reported here) are quite robust.

Note 13. In order to take into account potential serial correlation in the error terms, the lagged dependent variable was also included in the original regressions. Since this term was not statistically significant, it was not included in the results reported here.

\section{Copyright Disclaimer}

Copyright reserved by the author(s).

This article is an open-access article distributed under the terms and conditions of the Creative Commons Attribution license (http://creativecommons.org/licenses/by/3.0/). 